\title{
Gebelik Esnasında Yapılan Cinsel Aktivitenin Doğum Eyleminin Başlamasına ve Doğum Komplikasyonlarına Etkisi
}

\section{The Effect of Sexual Activity in Pregnancy on Beginning of Labor and Pregnancy Complications}

\author{
${ }^{1}$ Aysun TEKELİ TAŞKÖMÜR, ${ }^{2}$ Özlem ERTEN \\ ${ }^{1}$ Amasya Üniversitesi Tıp Fakültesi, Kadın Hastalıkları ve Doğum Anabilim Dalı, Amasya, Türkiye \\ ${ }^{2}$ Kütahya Sağlık Bilimleri Üniversitesi Tıp Fakültesi, Kadın Hastalıkları ve Doğum Anabilim Dalı, Kütahya, Türkiye
}

Aysun Tekeli Taşkömür: https://orcid.org/0000-0001-7839-6963

Özlem Erten: https://orcid.org/0000-0002-3178-8297

\section{ÖZ}

Amaç: Doğumu başlamak için tıbbi ilaçlar veya yöntemler kullanmak yerine, doğal bir yöntem olarak cinsel aktivitenin doğumun başlangıcına olan etkisinin araştırılması amaçland1.

Materyal ve Metot: Çalışmaya aktif doğumu başlayan 30 haftayı aşan tüm gebelikler dahil edildi. Kontrol grubunu gebeliğin son 12 haftasında hiç cinsel aktivitesi olmayanlar oluştururken, son haftaya kadar cinsel aktiviteleri devam eden gebeler ise çalışma grubunu oluşturdu. Her iki grubun demografik özellikleri, doğum haftas1, preterm eylem, postmatürite sayıları, travay esnasınada indüksiyon kullanımı, en son cinsel aktivite zamanı ve sıklığı sorgulandi. Çalışmaya toplam 800 hasta dahil edildi.

Bulgular: Kontrol grubunda sezaryen ve erken doğum oranı daha düșük ve postmatürite sayısı daha yüksek bulunmasına rağmen bu fark istatistiksel olarak anlamlı değildi $(p>0,05)$. Ancak çalışma grubunda uygulanan indüksiyon sayısının anlamlı olarak daha fazla olduğu görüldü $(\mathrm{p}<0,05)$.

Sonuç: Çalışmanın sonuçlarına göre gebelik esnasında cinsel aktiviteye devam etmek doğumda yapılan indüksiyon sayısını azaltabilir.

Anahtar Kelimeler: Cinsel aktivite, gebelik, postmatürite, preterm eylem

\section{ABSTRACT}

Objective: Instead of using medical drugs or methods to start labor, it was aimed to investigate the effect of sexual activity on the onset of labor as a natural method.

Materials and Methods: All pregnancies over 30 weeks that started active delivery were included in the study. Those who had no sexual activity in the last 12 weeks of pregnancy constituted the control group and pregnant women whose sexual activity continued until the last week constituted the study group. In addition to the demographic features of both groups, the birth week of the pregnant women, whether there was premature birth or postmaturity, induction use during labor, the time of the most recent sexual activity, and the frequency were questioned. A total of 800 patients were included in the study. Results: Although the rate of cesarean and preterm labor was lower and the number of postmaturity deliveries was higher in the control group, this difference was not statistically significant $(p>0.05)$. However, it was observed that the number of inductions performed in the study group was significantly lower $(\mathrm{p}<0.05)$.

Conclusion: According to the study results, continuing sexual activity during pregnancy could decrease the need for labor induction.

Keywords: Postmaturity, pregnancy, preterm labor, sexual activity
Sorumlu Yazar / Corresponding Author:

Aysun Tekeli Taşkömür

Kirazlidere Neighborhood Turgut Özal Street, Amasya, Turkey

Tel: +90 5534795680

E-mail: dr.isoon77@hotmail.com
Yayın Bilgisi / Article Info:

Gönderi Tarihi/ Received: 16/12/2020

Kabul Tarihi/ Accepted: 21/03/2021

Online Yayın Tarihi/ Published: 05/06/2021

Atıf / Cited: Tekeli Taşkömür A and Erten Ö. The Effect of Sexual Activity in Pregnancy on Beginning of Labor and Pregnancy Complications. Online Türk Sağllk Bilimleri Dergisi 2021;6(2):244-250. doi: 10.26453/otjhs.842068

\section{INTRODUCTION}

Post-term pregnancy (postmaturity) is defined as gestational age 42 weeks and above calculated from the first day of the last menstrual period. Perinatal mortality-morbidity increases especially in these weeks. ${ }^{1,2}$ For perinatal outcomes to be good, delivery must take place on time. Therefore, it can be planned to evaluate postmature pregnancies by giving case-by -case induction. 
Various methods are used today for labor induction. Pharmacologic methods, mechanical methods, membrane stripping, and amniotomy are among these methods. These methods may also have complications and usage difficulties. It has been suggested that sexual activity also accelerates labor. It has been shown that prostaglandin $\mathrm{E}$ in the semen and nipple stimulation accelerate labor. ${ }^{3,4}$ It has also been shown that coitus and orgasm can increase preterm labor risk by causing the uterus to contract. ${ }^{5}$ In light of this information, it can be thought that sexual activity accelerates delivery. However, this idea has not been fully proven.

There are very few studies on this subject. The understanding that sexual activity is an ethical issue and that it is not safe during pregnancy creates a limitation in studies. We conducted our study retrospectively by questioning the sexual activities of pregnant women who started active labor at 30 weeks or later.

\section{MATERIALS AND METHODS}

The study was conducted in Amasya Sabuncuoğlu Şerefeddin Training and Research Hospital between June 2017 and February 2018. The study was approved by the Medicine Clinical Research Ethics Committee of Hitit University Faculty (Date: 19/09/2017, decision no: 74).

Patients who started active labor and presented to the delivery room of our hospital at 30 weeks or later between the specified dates were included in the study. The inclusion criteria for active labor were: membrane rupture, onset of cervical dilation, and regular contractions in a non-stress test (NST). Patients with emergency conditions that might affect the time of birth such as gestational diabetes, hypertension, preeclampsia, and those with conditions such as placenta previa where sexual intercourse is prohibited were excluded from the study.

Patients who were informed about the study and those who wanted to participate in the study were asked about pregnancy information and sexual activities. The patients' age, gravida, parity, previous births, if any, height, weight, education level, history of previous surgery, current systemic diseases, date of the last sexual intercourse during pregnancy, and the number of sexual activities per week were questioned. In the follow-up, it was recorded how the patient gave birth and whether induction was applied. The frequency of sexual intercourse was classified as once, twice per week, more than twice per week, once every two weeks, once every three weeks, and once every four weeks. The last sexual intercourse was noted as a week ago, two weeks ago, three weeks ago, etc. The patients were divided into two groups as those who did or did not have sexual intercourse in the last 12 weeks or more, and those who had sexual intercourse during pregnancy until they gave birth. A total of 800 patients, including 400 patients in each group, were included in the study.

Statistical Analysis: The sample of this study was calculated with the G Power 3.1 computer program. According to the power analysis, the minimum sample size was determined as 772 (386 experiments, 386 controls) in order to reach $95 \%$ power with 0.5 effect size and $5 \%$ error margin.

The data obtained in this study were analyzed with a licensed SPSS 21 package program. The ShapiroWilk test was used due to the number of units when investigating the normal distribution of variables. When examining the differences between the groups, Mann-Whitney $U$ test was used if the variables did not have a normal distribution. While examining the relationships between groups of nominal variables, Chi-square analysis was used. In cases where the expected values in the cells did not have a sufficient number in $2 \times 2$ tables, Fisher's exact test was used. In the RxC tables, Pearson's Chi-square analysis was used with Monte Carlo simulation. When interpreting the results, 0.05 was used as the level of significance. $\mathrm{P}<0.05$ was considered statistically significant.

\section{RESULTS}

When the demographic and characteristic features of the women in both groups of the study were examined, there was no difference between the groups in terms of age, education level, body mass index (BMI), parity, current chronic disease, and number of previous non-cesarean surgeries $(\mathrm{p}>0.05)$ (Table 1). Education level had an effect on continuing sexual activity during pregnancy, but there was no significant relationship $(\mathrm{p}>0.05)$ (Table 1$)$.

The group that continued sexual intercourse was composed of patients whose last sexual intercourse was in the last 6 weeks of pregnancy, and the group that did not continue sexual intercourse consisted of patients who did not have sexual intercourse in the last 12 weeks. Thirty-three percent $(n=132)$ of the group continuing sexual intercourse had sexual activity a week ago, $22 \%(n=88)$ two weeks ago, $14.5 \%$ $(n=58)$ three weeks ago, and 24.25\% ( $n=97)$ four weeks ago (Table 2). The frequency of sexual activity was higher in the group that continued sexual 
intercourse in the frequency of intercourse by weekly time periods (Table 2$)$.

According to the data obtained at the end of the study, there was no difference in the mean birth weeks of the groups. In the group where sexual activity continued during pregnancy, the average week of birth was 38.57 , whereas in the group where sexual activity did not continue, the week of birth was determined as $38.68(\mathrm{p}>0.05)$ (Table 3$)$. The rate of ce-sarean delivery was $10.75 \%(n=43)$ in the group whose sexual activity did not continue during pregnancy, and it was $12.25 \%(\mathrm{n}=49)$ in the group whose sexual activity continued during pregnancy. The cesarean rate was higher in the group with sexual intercourse, but the difference was not statistically significant. There was no significant difference in the cesarean indications of the groups $(\mathrm{p}>0.05)$ (Table 3 ). There were $27(6.8 \%)$ preterm labors in the group with sexual intercourse, and 19 (4.8\%) preterm labors in the group without sexual intercourse. The number of preterm labors was higher in the group with sexual intercourse, but the difference was not significant ( $\mathrm{p}>0.05)$ (Table 3).

In the group with sexual intercourse, there were 91 (22.8\%) patients giving birth between $40-41$ weeks, and $10(2.5 \%)$ patients at 41 weeks and over. In the group without sexual intercourse during pregnancy, there were $101(25.3 \%)$ patients between 40-41 weeks and $16(4.0 \%)$ patients at 41 weeks or more. Although the number of postmaturity deliveries was higher in the group without sexual activity during pregnancy, the difference was not significant $(\mathrm{p}>0.05)$ (Table 3). Also, the need for labor induction in the groups was compared. Induction was performed in $37 \%(n=71)$ of patients in the group who continued to have sexual intercourse during pregnancy, and in $63 \%(\mathrm{n}=121)$ of patients who did not continue to have sexual intercourse during pregnancy. It was found that the rate of labor induction was significantly lower in the group that continued sexual intercourse during pregnancy $(\mathrm{p}<0.05)$ (Table 3).

\section{DISCUSSION AND CONCLUSION}

Induction is required in approximately $20 \%$ of all pregnancies, $79 \%$ of these are postmature pregnancies, which is quite high. ${ }^{6}$ For this reason, the search for a method other than medication to reduce the number of postmature pregnancies and the number of inductions continues today. Because sexual activity during pregnancy is also an ethical issue, this situation also restricts studies that investigate the effec- tiveness of sexual activity on the acceleration of labor.

The concern that sexual activity is not safe during pregnancy is a universal problem. Although it is emphasized in the antenatal care guide of the National Institute of Clinical Excellence (NICE) in England that sexual activity does not cause unwanted results during pregnancy, this concern continues in $20-80 \%$ of pregnant women. ${ }^{7}$ This rate is $40 \%$ in Nigeria, $45.4 \%$ in Pakistan, $49 \%$ in Canada, and $80 \%$ in Japan. ${ }^{8-11}$ In our study, pregnant women in the group who did not engage in sexual activity, especially in the last 12 weeks of pregnancy, stated that they stopped sexual activity because of the concern that there would be harm. For this reason, we can evaluate the anxiety rate as at least $50 \%$ in our study. There was no significant difference between the groups regarding the relationship between continuity of sexual activity and education level. Anxiety about what could happen to the baby could be seen with any level of education ( $p>0.05)$ (Table 1).

It is believed that sexual activity accelerates labor. During sexual activity, contact of the semen containing prostaglandin $\mathrm{E}$ with the cervix and nipple stimulation may cause uterine contractions. In the study conducted by Tan et al., regular sexual intercourse was recommended for pregnant women at 36 weeks and over, and the onset of birth and the induction rates used until the 41 st week were evaluated. ${ }^{7}$ It was shown that the need for induction of labor was lower in the group with coitus and the deliveries started earlier than in the control group. In the study of Omar et al., the effectiveness of sexual activity during pregnancy on the week of birth, the number of inductions used, and the duration of labor could not be demonstrated. ${ }^{12}$ In our study, the frequency of sexual activity by week and the last time of intercourse were asked of the pregnant women who came to the delivery room and started active labor at 30 weeks and over. The comparison of pregnant women who abandoned sexual activity in the last 12 weeks or earlier and those who were sexually active until the end of pregnancy was made. According to the results, there was no significant difference between the two groups in terms of the number of postmature pregnancies. However, it was found that less induction was performed in the group whose sexual activity continued during pregnancy, and this difference was significant $(\mathrm{p}<0.05)$.

The effect of sexual activity on preterm delivery is uncertain. In addition to studies showing that sexual activity in early pregnancy causes preterm labor, 
there are also studies showing that sexual activity in late pregnancy reduces the risk of preterm labor. $3,5,12$ In our study, there were $27(6.8 \%)$ preterm births in the group whose sexual activity continued and 19 $(4.8 \%)$ in the group that did not continue sexual activity. The number of preterm births was high in the group whose sexual activity continued, but this difference was not statistically significant $(\mathrm{p}=0.230)$.

In conclusion, suggesting sexual activity to couples in late pregnancy can naturally help birth by itself and reduce the need for induction. If this view is supported by more comprehensive studies, it may be possible to decrease the number of postmature pregnancies as well as perinatal morbidity and mortality.

Ethics Committee Approval: Our study was approved by the Medicine Clinical Research Ethics Committee of Hitit University Faculty (Date: 19/09/2017, decision no: 74).

Conflict of Interest: No conflict of interest was declared by the author.

Author Contributions: Concept - ATT, ÖE; Supervision - ATT, ÖE; Materials - ATT, ÖE; Data Collection and Processing - ATT, ÖE; Analysis and Interpretation - ATT, ÖE; Writing - ATT, ÖE.

Peer-review: Externally peer-reviewed.

\section{REFERENCES}

1. Vitale SG, Marilli I, Rapisarda AM, Iapichino V, Stancanelli F, Cianci A. Diagnosis, antenatal surveillance and management of prolonged pregnancy: current perspectives. Minerva Ginecol. 2015;67(4):365-373.

2. American College of Obstetricians and Gynecologists. Practice bulletin no. 146: Management of late-term and postterm pregnancies. Obstet Gynecol. 2014;124(2):390-396.

3. Sayle AE, Savitz DA, Thorp JM, Hertz-Picciotto I, Wilcox AJ. Sexual activity during late pregnancy and risk of preterm delivery. Obstet Gynecol. 2001;97(2):283-289.

4. Perkins RP. Sexual behavior and response in relation to complications of pregnancy. Am J Obstet Gynecol. 1979;134(5):498-505.

5. Petridou E, Salvanos H, Skalkidou A, Dessypris N, Moustaki M, Trichopoulos D. Are there common triggers of preterm deliveries? BJOG. 2001;108(6):598-604.

6. Nicholson JM, Kellar LC, Henning GF, Waheed A, Colon-Gonzalez M, Ural S. The association between the regular use of preventive labour induction and improved term birth outcomes: fin- dings of a systematic review and meta-analysis. BJOG. 2015;122(6):773-784.

7. Tan PC, Andi A, Azmi N, Noraihan MN. Effect of coitus at term on length of gestation, induction of labor, and mode of delivery. Obstet Gynecol. 2006;108(1):134-140.

8. Orji EO, Ogunlola IO, Fasubaa OB. Sexuality among pregnant women in South West Nigeria. J Obstet Gynecol. 2002;22(2):166-168.

9. Naim M, Bhutto E. Sexuality durin pregnancy in Pakistani women. J Pak Med Assoc. 2000;50 (1):38-44.

10. Bartellas E, Crane JM, Daley M, Bennett KA, Hutchens D. Sexuality and sexual activity in pregnancy. BJOG. 2000;107(8):964-968.

11. Fok WY, Chan LY, Yuen PM. Sexual behavior and activity in Chinese pregnant women. Acta Obstet Gynecol Scand. 2005;84(10):934-938.

12. Omar NS, Tan PC, Sabir N, Yusop ES, Omar SZ. Coitus to expedite the onset of labour: a randomised trial. BJOG. 2013;120(3):338-345. 
Table 1. Demographic and characteristic features of the groups.

\begin{tabular}{|c|c|c|c|c|}
\hline & & $\begin{array}{c}\text { Group with sexual } \\
\text { intercourse }\end{array}$ & $\begin{array}{c}\text { Group without sexual } \\
\text { intercourse }\end{array}$ & $\mathbf{P}$ \\
\hline \multicolumn{2}{|l|}{ Age (year) } & $27.03 \pm 5.53$ & $27.49 \pm 5.20$ & 0.181 \\
\hline \multicolumn{2}{|l|}{ BMI } & $28.53 \pm 3.94$ & $28.28 \pm 3.96$ & 0.266 \\
\hline \multirow[t]{2}{*}{ Parity } & Nulliparity & $160(40.0 \%)$ & $184(46.0 \%)$ & \multirow[t]{2}{*}{0.087} \\
\hline & Multiparity & $240(60.0 \%)$ & $216(54.0 \%)$ & \\
\hline \multirow[t]{5}{*}{ Education level } & Literate & $21(5.25 \%)$ & $16(4.0 \%)$ & \multirow[t]{5}{*}{0.609} \\
\hline & Primary school & $94(23.5 \%)$ & $88(22.0 \%)$ & \\
\hline & Middle school & $94(23.5 \%)$ & $112(28.0 \%)$ & \\
\hline & High school & $135(33.75 \%)$ & $127(31.75 \%)$ & \\
\hline & University & $56(14 \%)$ & $57(14.25 \%)$ & \\
\hline \multirow{2}{*}{ Current disease } & Yes & $33(8.25 \%)$ & $31(7.75 \%)$ & \multirow{2}{*}{0.794} \\
\hline & No & $367(91.75 \%)$ & $369(92.25 \%)$ & \\
\hline \multirow{2}{*}{ Previous surgery } & Yes & $54(13.5 \%)$ & $56(14.0 \%)$ & \multirow[t]{2}{*}{0.837} \\
\hline & No & $346(86.5 \%)$ & $344(86.0 \%)$ & \\
\hline
\end{tabular}

$p$-values were calculated with Mann Whitney U Test (age, BMI), and Chi-Square Test. 
Table 2. Comparison of frequency of sexual activity and recent sexual intercourse in groups.

\begin{tabular}{|l|l|c|c|}
\hline \multicolumn{2}{|l|}{} & $\begin{array}{c}\text { Sexual intercourse } \\
\text { group }\end{array}$ & $\begin{array}{c}\text { No sexual inter- } \\
\text { course group }\end{array}$ \\
\hline \multirow{4}{*}{$\begin{array}{l}\text { What is the frequency } \\
\text { of sexual intercourse of } \\
\text { the pregnant woman? }\end{array}$} & Once a week & $206(51.5 \%)$ & $210(52.5 \%)$ \\
\cline { 2 - 4 } & Two or more per week & $144(36.0 \%)$ & $17(4.25 \%)$ \\
\cline { 2 - 4 } & Once every two weeks & $46(11.5 \%)$ & $85(21.25 \%)$ \\
\cline { 2 - 4 } & Once every three weeks & $4(1.0 \%)$ & $24(6.0 \%)$ \\
\cline { 2 - 4 } & Once every four weeks & $0(0.0 \%)$ & $64(16.0 \%)$ \\
\cline { 2 - 4 } & Once every five weeks & $0(0.0 \%)$ & $0(0.0 \%)$ \\
\cline { 2 - 4 } & Once every six weeks & $0(0.0 \%)$ & $0(0.0 \%)$ \\
\hline \multirow{4}{*}{$\begin{array}{l}\text { What is the last sexual } \\
\text { intercourse time? }\end{array}$} & One week ago & $132(33.0 \%)$ & $0(0.0 \%)$ \\
\cline { 2 - 4 } & Two weeks ago & $88(22.0 \%)$ & $0(0.0 \%)$ \\
\cline { 2 - 4 } & Three weeks ago & $58(14.5 \%)$ & $0(0.0 \%)$ \\
\cline { 2 - 4 } & Four weeks ago & $97(24.25 \%)$ & $0(0.0 \%)$ \\
\cline { 2 - 4 } & Five weeks ago & $3(0.75 \%)$ & $0(0.0 \%)$ \\
\cline { 2 - 4 } & Six weeks ago & $22(5.5 \%)$ & $1(0.25 \%)$ \\
\cline { 2 - 4 } & 12 weeks ago & $0(0.0 \%)$ & $258(64.5 \%)$ \\
\cline { 2 - 4 } & $14-17$ weeks ago & $0(0.0 \%)$ & $27(6.75 \%)$ \\
\cline { 2 - 4 } & $18-20$ weeks ago & $0(0.0 \%)$ & $17(4.25 \%)$ \\
\cline { 2 - 4 } & $23-27$ weeks ago & $0(0.0 \%)$ & $18(4.50 \%)$ \\
\cline { 2 - 4 } & $28-32$ weeks ago & $0(0.0 \%)$ & $49(12.25 \%)$ \\
\cline { 2 - 4 } & $33-36$ weeks ago & $0(0.0 \%)$ & $30(7.50 \%)$ \\
\hline
\end{tabular}


Table 3. Comparison of birth week, delivery type, cesarean indication, postmaturity, preterm labor, and induction numbers of the groups.

\begin{tabular}{|c|c|c|c|c|}
\hline & & $\begin{array}{l}\text { Sexual inter- } \\
\text { course group }\end{array}$ & $\begin{array}{l}\text { No sexual } \\
\text { intercourse } \\
\text { group }\end{array}$ & $\mathbf{P}$ \\
\hline \multicolumn{2}{|l|}{ Birth week } & $38.57 \pm 1.28$ & $38.68 \pm 1.39$ & 0.432 \\
\hline \multirow[t]{2}{*}{ Delivery type } & Normal & $351(87.75 \%)$ & $357(89.25 \%)$ & \multirow[t]{2}{*}{0.506} \\
\hline & Cesarean & $49(12.25 \%)$ & $43(10.75 \%)$ & \\
\hline \multirow{6}{*}{$\begin{array}{l}\text { Cesarean indica- } \\
\text { tion }\end{array}$} & Fetal distress & $20(40.82 \%)$ & $16(37.21 \%)$ & \multirow{6}{*}{0.006} \\
\hline & CPD & $16(32.65 \%)$ & $12(27.91 \%)$ & \\
\hline & Non-progressive labor & $0(0.0 \%)$ & $7(16.28 \%)$ & \\
\hline & Prolonged labor & $13(26.53 \%)$ & $5(11.63 \%)$ & \\
\hline & Ablation placenta & $0(0.0 \%)$ & $2(4.65 \%)$ & \\
\hline & Preeclampsia & $0(0.0 \%)$ & $1(2.33 \%)$ & \\
\hline \multirow[t]{2}{*}{ Preterm labor } & Yes & $27(6.8 \%)$ & $19(4.89 \%)$ & \multirow[t]{2}{*}{0.230} \\
\hline & No & $373(93.3 \%)$ & $381(95.3 \%)$ & \\
\hline \multirow[t]{3}{*}{ Postmaturity } & 40-41 weeks & $91(22.8 \%)$ & $101(25.3 \%)$ & \multirow{3}{*}{0.674} \\
\hline & 41weeks and over & $10(2.5 \%)$ & $16(4.0 \%)$ & \\
\hline & No & $299(74.8 \%)$ & $283(70.8 \%)$ & \\
\hline \multirow{2}{*}{$\begin{array}{l}\text { Need for induction } \\
\text { to start labor }\end{array}$} & Yes & $71(37.0 \%)$ & $121(63.0 \%)$ & \multirow{2}{*}{$<0.001$} \\
\hline & No & $329(54.1 \%)$ & $279(45.9 \%)$ & \\
\hline
\end{tabular}

$p$-values were calculated with Mann Whitney U Test (birth week), and Chi-Square Test (Monte Carlo simulation was applied). 